Article

\title{
Antimicrobial and Antioxidant Properties of Four Lycopus Taxa and an Interaction Study of Their Major Compounds
}

\author{
Eva Trajčíková ${ }^{1}$, Elena Kurin ${ }^{1}$, Lívia Slobodníková ${ }^{2}$, Marek Straka ${ }^{2,3}$, Aneta Lichváriková ${ }^{4}$, \\ Svetlana Dokupilová ${ }^{5}$, Iveta Čičová ${ }^{6}$, Milan Nagy ${ }^{1}$, Pavel Mučaji ${ }^{1}{ }^{1}$ and \\ Silvia Bittner Fialová ${ }^{1, *}$
}

1 Department of Pharmacognosy and Botany, Faculty of Pharmacy, Comenius University in Bratislava, Odbojárov 10, 83232 Bratislava, Slovakia; trajcikova1@uniba.sk (E.T.); elena.kurin@uniba.sk (E.K.); nagy@fpharm.uniba.sk (M.N.); mucaji@fpharm.uniba.sk (P.M.)

2 Institute of Microbiology, Faculty of Medicine and the University Hospital in Bratislava, Comenius University in Bratislava, Sasinkova 4, 81108 Bratislava, Slovakia; livia.slobodnikova@fmed.uniba.sk (L.S.); marek.straka@fmed.uniba.sk (M.S.)

3 Department of Microbiology and Virology, Faculty of Natural Sciences, Comenius University in Bratislava, Mlynská dolina, Ilkovičova 6, 84215 Bratislava, Slovakia

4 Department of Molecular Biology, Faculty of Natural Sciences, Comenius University in Bratislava, Mlynská dolina, Ilkovičova 6, 84215 Bratislava, Slovakia; lichvarikova.aneta@gmail.com

5 Department of Pharmaceutical Analysis and Nuclear Pharmacy, Faculty of Pharmacy, Comenius University in Bratislava, Odbojárov 10, 83232 Bratislava, Slovakia; dokupilova@fpharm.uniba.sk

6 National Agricultural and Food Centre, Research Institute of Plant Production, 92168 Piešt'any, Slovakia; iveta.cicova@nppc.sk

* Correspondence: fialova@fpharm.uniba.sk; Tel.: +421-250-117-206; Fax: +421-250-117-100

Academic Editor: Dimitris P. Makris

Received: 18 February 2020; Accepted: 17 March 2020; Published: 20 March 2020

\begin{abstract}
The compositions of leaf infusions of three genotypes of Lycopus europaeus L. with origins in central Europe, namely L. europaeus A (LeuA), L. europaeus B (LeuB), and L. europaeus C (LeuC), and one genotype of L. exaltatus (Lex), were examined by LC-MS-DAD (Liquid Chromatography Mass Spectrometry and Diode Array Detection) analysis. This revealed the presence of thirteen compounds belonging to the groups of phenolic acids and flavonoids, with a predominance of rosmarinic acid (RA) and luteolin-7-O-glucuronide (LGlr). The antimicrobial activity of leaf infusions was tested on the collection strains of Gram-positive and Gram-negative bacteria, and on the clinical Staphylococcus aureus strains. We detected higher activity against Gram-positive bacteria, of which the most susceptible strains were those of Staphylococcus aureus, including methicillin-resistant and poly-resistant strains. Furthermore, we examined the antioxidant activity of leaf infusions using 2,2-diphenyl-1-picrylhydrazyl (DPPH) and 2,2'-azino-bis(3-ethylbenzothiazoline-6-sulphonic acid) (ABTS) methods, and on NIH/3T3 cell lines using dichlorodihydrofluorescein diacetate (DCFH-DA). We also studied the mutual interactions between selected infusions, namely RA and/or LGlr. In the mixtures of leaf infusion and RA or LGlr, we observed slight synergism and a high dose reduction index in most cases. This leads to the beneficial dose reduction at a given antioxidant effect level in mixtures compared to the doses of the parts used alone. Therefore, our study draws attention to further applications of the Lycopus leaves as a valuable alternative source of natural antioxidants and as a promising topical antibacterial agent for medicinal use.
\end{abstract}

Keywords: Lycopus leaf infusion; antimicrobial activity; antioxidant activity; interaction study; rosmarinic acid; luteolin-7-O-glucuronide 


\section{Introduction}

Medicinal plants and herbal preparations have been traditionally used as mixtures of natural substances in phytomedicine for centuries [1]. There exist many good reasons for this practice, such as synergism among constituents, mutual protection of active substances due to their instability, or in some cases, the active substances are still unknown [2]. Synergy or antagonism is present when two or more ingredients of the complex mutually increase or decrease each other's effect. The final response is higher or lower than a simple summation of single effects (additivity) [3]. This can lead to enhancement in the efficacy of mixtures, reduction of their dosage, and decline of their adverse or toxic effects in clinical practice [4]. The synergistic combinations of agents can be more effective than single-drug treatment thanks to the decrease or even elimination of resistance development, especially in resistant bacteria or viruses [5]. Medicinal plants contain plenty of heterogeneous substances with a positive interaction potential, which makes them a promising area for synergy research.

Lycopus L. is a genus of approximately 16 species of flowering plants in the family Lamiaceae, subfamily Nepetoidae [6]. All are herbaceous and native to Europe, East Asia, and North America. The species are often grown in wetlands, damp meadows, stream banks, and other aquatic environments [7]. This genus is characterized by dentate or pinnatifid opposite leaves; flowers in compact, sessile verticillasters in the leaf axils; 4-5 lobed tubulate or campanulate calyces; and a dry, tetrahedral, one-seeded nutlet with corky crests [6,8]. The most important constituents of this genus are essential oil, terpenoids (mostly diterpenes and triterpenes), flavonoids, and phenolic and hydroxycinnamic acids [7,9].

Two species are commonly found in Europe, Lycopus europaeus L. and L. exaltatus L.f. The first one is a perennial plant native to Europe and Asia and naturalized in the U.S. The plant is odorless and has a bitter taste. Its herbal juice yields a black dye, supposedly used by gypsies to tan their skin, hence the common name of gypsywort. It is also known as the bugleweed, Wolfstrappkraut, bitter bugle, or water horehound [10-12].

The biological effects of this plant are attributed to phenolic compounds, mainly to derivatives of hydroxycinnamic acid and flavonoids. According to Fialová et al. [13], the major compounds in leaf infusion are rosmarinic acid and luteolin-7-O-glucuronide. Other extracts of the aerial parts revealed a high amount of isopimarane-type diterpenoids and alicyclic diterpenes $[9,14,15]$. L. europaeus is traditionally suggested for treating mild hyperthyroidism with vegetative nervous disturbances. It shows a clear reduction of hyperthyroid symptoms, particularly of cardiac symptoms, and increased body temperature. Extracts of the plant are traditionally also used in tenseness and pain of the mammary gland [15-19]. The methanol extract of the plant showed central and peripheral analgesic and anti-inflammatory effects, which could be associated with the presence of terpenoids, flavonoids, and tannins [11]. The same extract demonstrated significant antitussive activity by inhibition of cough reflex [10]. L. europaeus also possessed antiparasitic activity against T. gallinae [20], and antioxidant and antimicrobial activity against various bacterial species [12-15].

L. exaltatus is also native to Europe and Asia. Unlike the L. europaeus, the leaves of which are only coarsely serrate or sinuate, the leaves of L. exaltatus are deeply pinnatifid [21]. The phenolic fingerprints of L. exaltatus and L. europaeus are similar, as proven by Bucar and Kartnig [22].

Considering the antioxidant, anti-inflammatory, analgesic, and antimicrobial properties of $L$. europaeus, its extracts or isolated compounds might be helpful in the future as potential remedies for the treatment of infections in human or veterinary medicine. Therefore, the aim of our study was a detailed evaluation of the antimicrobial and antioxidant activity of three L. europaeus genotypes and one L. exaltatus genotype with origins in Central Europe, and to provide phytochemical analysis and fingerprinting of polar phenolic compounds in the leaf infusions. To the best of our knowledge, this is the first study on the biological activities of L. exaltatus. 


\section{Results}

\subsection{Identification and Quantification}

Secondary metabolites of four Lycopus leaf infusions were identified using Liquid ChromatographyTandem Mass Spectrometry (LC-MS/MS). Acquired MS spectra were compared with authentic standards or with database searches. The maximum allowed mass deviation was $10 \mathrm{ppm}$. Eleven compounds, including phenolic acids and flavonoids, were found in almost all samples. Identified secondary metabolites are presented in Table 1 , along with their retention times $\left(\mathrm{T}_{R}\right)$, observed mass in negative ionization mode, MS/MS fragment ions of each secondary metabolite, as well as their quantity in each infusion. The compounds detected in the analyzed infusions were characterized using MS data, together with the interpretation of the observed MS/MS spectra in comparison with standards and data listed in the available literature [13,22].

Table 1. Content compounds of Lycopus leaf infusions, their corresponding retention times $\left(\mathrm{T}_{\mathrm{R}}\right)$, molecular ions $\left[\mathrm{M}-\mathrm{H}^{-}\right.$, and $\mathrm{MS}^{2}$ fragments in LC-MS/MS analysis, in addition to quantitative abundance of polar phenolic compounds $(\mu \mathrm{g} / \mathrm{mL})$ in four Lycopus infusions.

\begin{tabular}{|c|c|c|c|c|c|c|c|c|}
\hline & \multirow{2}{*}{ Compound } & \multirow{2}{*}{$\underset{(\min )}{T_{R}}$} & \multirow{2}{*}{$[\mathbf{M}-\mathbf{H}]^{-}$} & \multirow{2}{*}{$\begin{array}{c}\mathrm{MS}^{2} \\
(20 \mathrm{eV})(\mathrm{m} / z)\end{array}$} & \multicolumn{4}{|c|}{ Mass Concentration $(\mu \mathrm{g} / \mathrm{mL})^{*} \pm \mathrm{SD}$} \\
\hline & & & & & LeuA & LeuB & LeuC & Lex \\
\hline 1 & Citric acid & 4.76 & 191.0191 & $\begin{array}{c}111.0084 \\
87.0087 \\
85.037\end{array}$ & ND & LOD & LOD & LOD \\
\hline 2 & $\begin{array}{c}\text { Danshensu } \\
\text { (trihydroxyphenyl } \\
\text { propanoic acid) }\end{array}$ & 11.64 & 197.0449 & $\begin{array}{l}179.0343 \\
135.0443\end{array}$ & LOD & LOD & LOD & LOD \\
\hline 3 & Caffeic acid & 21.59 & 179.0342 & 135.0445 & $15.7 \pm 1.7$ & $16.8 \pm 0.2$ & $16.9 \pm 0.1$ & $23.1 \pm 0.1$ \\
\hline 4 & Quercetin glucuronide & 24.58 & 477.0656 & 301.0332 & $38.1 \pm 1.4$ & $21.5 \pm 0.3$ & ND & $84.3 \pm 0.3$ \\
\hline 5 & Quercetin glucoside & 25.91 & 463.0857 & $\begin{array}{l}301.0324 \\
359.0739 \\
197.0456\end{array}$ & $34.0 \pm 7.7$ & LOD & LOD & LOD \\
\hline 6 & Lithospermic acid & 26.00 & 537.1034 & $\begin{array}{l}179.0340 \\
161.0235 \\
135.0431 \\
359.0767\end{array}$ & LOD & LOD & LOD & $13.9 \pm 0.1$ \\
\hline 7 & Rosmarinic acid hexoside & 28.42 & 521.1301 & $\begin{array}{l}179.0376 \\
161.0223\end{array}$ & LOD & $17.4 \pm 0.6$ & $16.3 \pm 0.5$ & LOD \\
\hline 8 & Luteolin-7-O-glucuronide & 28.57 & 461.0731 & $\begin{array}{l}285.0393 \\
359.0751\end{array}$ & $315.1 \pm 3.6$ & $279.6 \pm 1.4$ & $275.1 \pm 0.9$ & $449.8 \pm 0.4$ \\
\hline 9 & Sagerinic acid & 29.96 & 439.0318 & $\begin{array}{l}197.8040 \\
161.0232 \\
539.1182\end{array}$ & $12.0 \pm 2.4$ & $15.4 \pm 0.3$ & $12.4 \pm 0.2$ & $11.1 \pm 4.2$ \\
\hline 10 & Sulphated rosmarinic acid & 30.37 & 719.1620 & $\begin{array}{l}359.0774 \\
161.0450\end{array}$ & $11.8 \pm 0.6$ & $18.7 \pm 0.1$ & $16.6 \pm 0.4$ & $13.0 \pm 0.1$ \\
\hline 11 & Apigenin-7-O-glucuronide & 34.12 & 445.0753 & 269.0444 & $27.6 \pm 0.1$ & $23.0 \pm 2.7$ & $36.5 \pm 1.2$ & $27.2 \pm 0.1$ \\
\hline 12 & Rosmarinic acid & 34.48 & 359.0751 & $\begin{array}{l}197.0483 \\
161.0234\end{array}$ & $213.7 \pm 0.3$ & $237.5 \pm 0.8$ & $202.3 \pm 0.1$ & $216.2 \pm 0.1$ \\
\hline 13 & Caffeic acid derivative & 36.52 & 549.2332 & $\begin{array}{l}359.0767 \\
161.0295\end{array}$ & $19.6 \pm 0.3$ & LOD & $7.6 \pm 0.2$ & $168.0 \pm 0.3$ \\
\hline
\end{tabular}

*Values $(\mu \mathrm{g} / \mathrm{mL}$ infusion) are presented as means \pm standard deviation $(n=3)$; external standards: luteolin-7-O-glucuronide (used for flavonoid determination), rosmarinic acid (used for phenolic acid determination). $\mathrm{ND}-$ not detected; $\mathrm{LOD}-$ limit of detection, $\mathrm{T}_{\mathrm{R}}$ - retention time, LeuA-L. europaeus A; LeuB-L. europaeus $\mathrm{B}$; LeuC—L.europaeus C; Lex-L. exaltatus;

Peak 1, which presented a pseudomolecular $[\mathrm{M}-\mathrm{H}]^{-}$ion at $m / z 191$, with all typical product ions presented at $m / z 111,87$, and 85, was identified as citric acid. Danshensu (trihydroxyphenyl propanoic acid) was identified as the second compound with the precursor ion $[\mathrm{M}-\mathrm{H}]^{-}$at $m / z 197$ and product ions at $m / z 179$ and 135. Caffeic acid was identified at a retention time of 21.59 min, with a molecular $[\mathrm{M}-\mathrm{H}]^{-}$ion identified at $m / z 179$ and product ion at $m / z 135$ (which is attributed to the loss of $\mathrm{CO}_{2}$ ), and was compared with an authentic standard. The small peak at 24.58 min is most probably flavonoid quercetin glucuronide with precursor ion $[\mathrm{M}-\mathrm{H}]^{-}$at $m / z 477$ and with aglycone ion at $m / z$ 301. Peak 5 showed a precursor ion at $m / z 463[\mathrm{M}-\mathrm{H}]^{-}$and its MS/MS spectrum presented a product ion at $\mathrm{m} / \mathrm{z} 301$ belonging to quercetin glucoside. Lithospermic acid was detected in $26 \mathrm{~min}$, with a 
molecular ion $[\mathrm{M}-\mathrm{H}]^{-}$at $m / z 537$ and typical fragments at $m / z 359,197,179,161$, and 135 . A small peak (peak 7) presented a pseudomolecular $[\mathrm{M}-\mathrm{H}]^{-}$ion at $m / z 521$, with fragmentation products at $m / z 359$ [M-H-162 $]^{-}, 179$, and 161. This peak was identified according to literature as rosmarinic acid hexoside [23]. One of two dominant peaks was recorded in $28.57 \mathrm{~min}$ and was identified and compared with authentic standard luteolin-7-O-glucuronide (LGlr), with a typical MS [M - H] $]^{-}$ion at $m / z 461$ and product ion at $m / z$ 285. Peak 9, sagerinic acid, a caffeic acid derivative, was identified based on molecular ion $[\mathrm{M}-\mathrm{H}]^{-}$at $m / z 719$, yielding fragments at $m / z 539,359$, and 161. Peak 10, sulfated rosmarinic acid, was identified according to the literature [23]. It showed the molecular ion $[\mathrm{M}-\mathrm{H}]^{-}$at $m / z 439$ and a product ion at $m / z 359$ due to the loss of $80 \mathrm{Da}$ (sulfated moiety). A small peak at 34.12 min belonged to apigenin-glucuronide, with molecular ion $[\mathrm{M}-\mathrm{H}]^{-}$at $m / z 445$ and with aglycone ion at $\mathrm{m} / \mathrm{z} 269$. The most dominant peak at $34.48 \mathrm{~min}$ revealed the expected presence of the main compound rosmarinic acid (RA), with $[\mathrm{M}-\mathrm{H}]^{-}$at $m / z 359$. Peak 13 was identified as a caffeic acid derivative, with $[\mathrm{M}-\mathrm{H}]^{-}$at $m / z 549$ and fragments at $m / z 359$ and 161.

The phenolic compounds present in the samples were characterized according to their UV, mass spectra, and retention times, and by comparison with authentic standards when available. For the quantitative analysis, external standards were used. We used LGlr (at $\lambda=360 \mathrm{~nm}$ ) for the determination of flavonoids and their derivatives, and RA (at $\lambda=320 \mathrm{~nm}$ ) for the determination of phenolic acids and their derivatives. Their calibration curves were obtained by injection of known concentrations (5-100 ppm). Both standards showed good linearity. The following $\mathrm{r}^{2}$ values were obtained: LGlr $r^{2}=0.9976$, regression curve $y=237.26 x-450.72$ and $R A r^{2}=0.999$, regression curve $y=340.5 x+$ 297.09. The limit of detection (LOD) of LGlr was $1.89 \mu \mathrm{g} / \mathrm{mL}$ and the limit of quantification (LOQ) was $6.31 \mu \mathrm{g} / \mathrm{mL}$. The LOD of RA was $1.33 \mu \mathrm{g} / \mathrm{mL}$ and the LOQ was $4.45 \mu \mathrm{g} / \mathrm{mL}$. The results were expressed in $\mu \mathrm{g}$ per $\mathrm{mL}$ of leaf infusion. The examinations of secondary metabolites in Lycopus leaf infusions were performed in triplicate. The quantitative results were calculated from calibration curves, expressed as mean values and standard deviation (SD).

\subsection{Evaluation of Antimicrobial Activity}

The antimicrobial activity of the Lycopus infusions was tested using microorganisms most frequently isolated from local infections in humans. Collection strains of Staphylococcus aureus, Enterococcus faecalis, Pseudomonas aeruginosa, Escherichia coli, Klebsiella pneumoniae, and Proteus mirabilis, as well as 28 clinical S. aureus strains and one collection strain of a yeast Candida albicans, were included. For the first screening, 7 well-characterized collection strains were used (for details see the "Material and methods"). The results of antibacterial activities of the four tested Lycopus infusions on bacterial collection strains are shown in Table 2.

Staphylococci were the most susceptible; the minimal inhibitory concentrations (MIC) and minimal bactericidal concentrations (MBC) of Lycopus infusions were between 2.5 and $5 \mathrm{mg} / \mathrm{mL}$ in both methicillin-resistant S. aureus (CCM 4750) and methicillin-susceptible S. aureus (CCM4223) S. aureus strains. The most susceptible Gram-negative bacterial species was Proteus mirabilis, with MICs and MBCs between 2.5 and $10 \mathrm{mg} / \mathrm{mL}$. Concerning the yeast strain of Candida albicans CCM 90028, it was found to be resistant against any of the samples in the tested concentration range. When comparing the examined plant infusions, the L. exaltatus (Lex) infusion was slightly less active than those of L. europaeus.

Based on the results with collection strains, the most effective sample-L. europaeus B (LeuB)—was chosen for further testing, while clinical strains of $S$. aureus were used as microbial targets. These strains were isolated from infected skin, soft tissue, and wounds (19 strains), and from bloodstream infections (9 strains). Out of 28 strains, 14 were resistant to methicillin or oxacillin (MRSA) and were mecA gene-positive. To ensure the appropriate variability of the tested strains, they had various antimicrobial susceptibility patterns and came from different Spa-types. MIC and MBC values of LeuB infusion for clinical S. aureus strains are shown in Table 3. 
Table 2. Activity of Lycopus infusions on the bacterial collection strains.

\begin{tabular}{|c|c|c|c|c|c|c|c|c|}
\hline \multirow{2}{*}{ Strain } & \multicolumn{2}{|c|}{ LeuA } & \multicolumn{2}{|c|}{ LeuB } & \multicolumn{2}{|c|}{ LeuC } & \multicolumn{2}{|c|}{ Lex } \\
\hline & $\underset{[\mathrm{mg} / \mathrm{mL}]}{\mathrm{MIC}}$ & $\begin{array}{c}\mathrm{MBC} \\
{[\mathrm{mg} / \mathrm{mL}]}\end{array}$ & $\underset{[\mathrm{mg} / \mathrm{mL}]}{\mathrm{MIC}}$ & $\begin{array}{c}\mathrm{MBC} \\
{[\mathrm{mg} / \mathrm{mL}]}\end{array}$ & $\underset{[\mathrm{mg} / \mathrm{mL}]}{\mathrm{MIC}}$ & $\begin{array}{c}\mathrm{MBC} \\
{[\mathrm{mg} / \mathrm{mL}]}\end{array}$ & $\underset{[\mathrm{mg} / \mathrm{mL}]}{\mathrm{MIC}}$ & $\begin{array}{c}\mathrm{MBC} \\
{[\mathrm{mg} / \mathrm{mL}]}\end{array}$ \\
\hline $\begin{array}{l}\text { S. aureus } \\
\text { CCM } 4223\end{array}$ & 2.5 & 2.5 & 2.5 & 2.5 & 2.5 & 2.5 & 5 & 5 \\
\hline $\begin{array}{l}\text { S. aureus } \\
\text { CCM } 4750\end{array}$ & 2.5 & 2.5 & 2.5 & 2.5 & 2.5 & 2.5 & 2.5 & 2.5 \\
\hline $\begin{array}{l}\text { E. faecalis } \\
\text { CCM } 4224\end{array}$ & $>40$ & $>40$ & 40 & $>40$ & 40 & $>40$ & 40 & 40 \\
\hline $\begin{array}{l}\text { P. aeruginosa } \\
\text { CCM } 3955\end{array}$ & 20 & 40 & 40 & $>40$ & 20 & 40 & 40 & 40 \\
\hline $\begin{array}{c}\text { E. coli } \\
\text { CCM } 3954\end{array}$ & 40 & 40 & 40 & $>40$ & $>40$ & $>40$ & 40 & $>40$ \\
\hline $\begin{array}{l}\text { K. pneumoniae } \\
\text { ССМ } 4415\end{array}$ & $>40$ & $>40$ & $>40$ & $>40$ & $>40$ & $>40$ & 40 & $>40$ \\
\hline $\begin{array}{l}\text { P. mirabilis } \\
\text { CCM } 7188\end{array}$ & 5 & 5 & 2.5 & 2.5 & 2.5 & 5 & 5 & 10 \\
\hline
\end{tabular}

Note: LeuA—L. europaeus A; LeuB—L. europaeus B; LeuC—L. europaeus C; Lex—L.exaltatus; MIC—minimal inhibitory concentration; $\mathrm{MBC}-$ minimal bactericidal concentration, CCM - Czech Collection of Microorganisms.

Table 3. Antimicrobial activity of L. europaeus B infusion against clinical Staphylococcus aureus strains, expressed as minimal inhibitory concentration and minimal bactericidal concentration versus number of inhibited and killed strains, respectively.

\begin{tabular}{cccccccc}
\hline $\begin{array}{c}\text { MIC } \\
{[\mathbf{m g} / \mathbf{m L}]}\end{array}$ & $\begin{array}{c}\text { Number of } \\
\text { Strains }(\%)\end{array}$ & $\begin{array}{c}\text { MRSA } \\
(\mathbf{n})\end{array}$ & $\begin{array}{c}\text { MSSA } \\
\mathbf{( n )}\end{array}$ & $\begin{array}{c}\text { MBC } \\
{[\mathbf{m g} / \mathbf{m L}]}\end{array}$ & $\begin{array}{c}\text { Number of } \\
\text { Strains }(\%)\end{array}$ & $\begin{array}{c}\text { MRSA } \\
(\mathbf{n})\end{array}$ & $\begin{array}{c}\text { MSSA } \\
(\mathbf{n})\end{array}$ \\
\hline 1.25 & $10(36 \%)$ & 8 & 2 & 1.25 & $9(32 \%)$ & 7 & 2 \\
2.5 & $18(64 \%)$ & 6 & 12 & 2.5 & $18(64 \%)$ & 7 & 11 \\
5 & - & - & - & 5 & $1(4 \%)$ & - & 1 \\
\hline
\end{tabular}

MIC-minimal inhibitory concentration; MBC-minimal bactericidal concentration; $\mathrm{n}$-number of strains; MRSA—methicillin-resistant S. aureus; MSSA—-methicillin-susceptible S. aureus.

As shown in Table 3, the antibacterial activity of LeuB infusion on clinical S. aureus strains was comparable to results obtained with the collection S. aureus strains (MICs were found in the interval from 1.25 to $2.5 \mathrm{mg} / \mathrm{mL}$; MBCs reached values from 1.25 to $5 \mathrm{mg} / \mathrm{mL}$ ). There was no correlation between the MIC or MBC values and the susceptibility of clinical strains to methicillin or to the other antibiotics.

\subsection{Antioxidant Activity by ABTS (2,2'-azino-bis(3-ethylbenzothiazoline-6-sulphonic acid), DPPH} (2,2-diphenyl-1-picrylhydrazyl), and DCFH-DA (dichlorodihydrofluorescein diacetate) Assays

All infusions showed antioxidant activity at the concentration range between 1.25 and $40 \mu \mathrm{g} / \mathrm{mL}$. The reference compounds, RA and LGlr, possessed antioxidant effects at the concentration range between 0.31 to $20 \mu \mathrm{g} / \mathrm{mL}$. All tested infusions showed concentration-dependent antioxidant activity. The concentration of a sample necessary to decrease the oxidative stress by $50 \%\left(\mathrm{IC}_{50}\right)$ under the experimental conditions was calculated and presented in Table 4 using CompuSyn software. Therefore, a lower $\mathrm{IC}_{50}$ value indicates a higher antioxidant activity. 
Table 4. The concentration of a sample necessary to decrease the oxidative stress by $50 \%\left(\mathrm{IC}_{50}\right)$ of plants infusions, rosmarinic acid, and luteolin-7-O-glucuronide by ABTS, DPPH, and DCFH-DA assay.

\begin{tabular}{|c|c|c|c|c|c|c|}
\hline \multirow{2}{*}{ Sample } & \multicolumn{2}{|l|}{ ABTS } & \multicolumn{2}{|l|}{ DPPH } & \multicolumn{2}{|c|}{ DCFH-DA } \\
\hline & $\mathrm{IC}_{50}(\mu \mathrm{g} / \mathrm{mL})$ & $r^{a}$ & $\mathrm{IC}_{50}(\mu \mathrm{g} / \mathrm{mL})$ & $r^{a}$ & $\mathrm{IC}_{50}(\mu \mathrm{g} / \mathrm{mL})$ & $r^{a}$ \\
\hline LeuA & 9.35 & 0.99 & 8.42 & 0.99 & 2.64 & 0.98 \\
\hline LeuB & 8.75 & 0.98 & 9.61 & 0.99 & 2.89 & 0.98 \\
\hline LeuC & 9.61 & 0.96 & 9.02 & 0.98 & 2.92 & 0.99 \\
\hline Lex & 10.41 & 0.97 & 8.30 & 0.98 & 2.17 & 0.97 \\
\hline LGlr & 7.37 & 0.96 & 3.29 & 0.99 & 0.94 & 0.98 \\
\hline RA & 2.20 & 0.97 & 1.81 & 0.99 & 0.63 & 0.99 \\
\hline
\end{tabular}

a $r$, linear correlation coefficient of the median-effect plot; LeuA-L. europaeus A; LeuB-L. europaeus B; LeuC-L.europaeus C; Lex-L. exaltatus; LGlr-luteolin-7-O-glucuronide; RA-rosmarinic acid; ABTS (2,2'-azino-bis(3-ethylbenzothiazoline-6-sulphonic acid), DPPH (2,2-diphenyl-1-picrylhydrazyl), DCFH-DA (dichlorodihydrofluorescein diacetate).

\subsection{Interaction Analysis by ABTS, DPPH, and DCFH-DA Assays}

As we discovered, the most abundant compounds of Lycopus leaf infusions were RA and LGlr. Therefore, we choose both substances for interaction analysis. Moreover, we also choose the most effective infusion for each method of antioxidant activity testing (LeuB for ABTS method and Lex for DCFH-DA and DPPH assays, respectively). Equivalent amounts of RA, LGlr, and selected infusions were tested for mutual interactions in mixtures using methods of antioxidant activity testing (ABTS, DPPH, and DCFH-DA). As can be seen in Table 5, all tested combinations showed the synergistic or nearly additive effect. The combination of RA and LGlr showed moderate synergism in all assays. We also provided the interaction analysis between different infusions, which was observed for additive effect only; therefore, we did not present those results here.

Table 5. Interaction analysis of Lycopus spp. infusions, luteolin-7-O-glucuronide, and rosmarinic acid.

\begin{tabular}{|c|c|c|c|c|c|c|c|}
\hline Method & $\begin{array}{c}\text { Sample } \\
\text { Combination }\end{array}$ & $\begin{array}{c}\mathrm{IC}_{50} \\
(\mu \mathrm{g} / \mathrm{mL})^{a}\end{array}$ & $r^{b}$ & $\mathrm{CI}^{c}$ & $\operatorname{SDA}^{d}$ & Combined Effect & $\operatorname{DRI}^{e}$ \\
\hline \multirow[t]{4}{*}{ ABTS } & LeuB:RA & 2.32 & 0.97 & 0.66 & \pm 0.01 & Synergism & 7.19:1.25 \\
\hline & LeuB:LGlr & 6.64 & 0.98 & 0.83 & \pm 0.01 & Moderate synergism & 2.64:2.22 \\
\hline & LGlr:RA & 2.74 & 0.98 & 0.81 & \pm 0.01 & Moderate synergism & 5.38:1.61 \\
\hline & LeuB:RA:LGlr & 3.39 & 0.99 & 0.80 & \pm 0.01 & Moderate synergism & 7.74:1.95:6.52 \\
\hline \multirow[t]{4}{*}{$\mathrm{DPPH}$} & Lex:RA & 2.75 & 0.96 & 0.93 & \pm 0.01 & Nearly additive effect & 6.03:1.31 \\
\hline & Lex:LGlr & 2.96 & 0.97 & 0.63 & \pm 0.01 & Synergism & $5.60: 2.22$ \\
\hline & LGlr:RA & 1.90 & 0.96 & 0.81 & \pm 0.03 & Moderate synergism & 3.46:1.90 \\
\hline & Lex:RA:LGlr & 2.57 & 0.99 & 0.84 & \pm 0.01 & Moderate synergism & $9.70: 2.12: 3.85$ \\
\hline \multirow[t]{4}{*}{ DCFH-DA } & Lex:RA & 0.73 & 0.98 & 0.74 & \pm 0.01 & Moderate synergism & $6.00: 1.74$ \\
\hline & Lex:LGlr & 0.98 & 0.98 & 0.75 & \pm 0.02 & Moderate synergism & 4.44:1.91 \\
\hline & LGlr:RA & 0.54 & 0.96 & 0.72 & \pm 0.02 & Moderate synergism & $3.45: 2.32$ \\
\hline & Lex:RA:LGlr & 0.58 & 0.99 & 0.61 & \pm 0.01 & Synergism & $11.16: 3.23: 4.80$ \\
\hline
\end{tabular}

${ }^{a} \mathrm{IC}_{50}(\mu \mathrm{g} / \mathrm{mL})$ of the equal mass concentration infusion combinations; ${ }^{\mathrm{b}} \mathrm{r}$-linear correlation coefficient of the

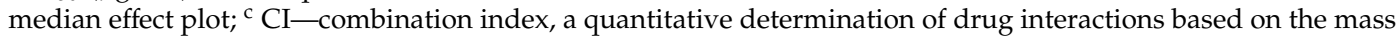
action law, where $\mathrm{CI}<1,=1$, and $>1$ indicate synergism, additive effect, and antagonism, respectively (the combined effect is evaluated according to Chou [24]); ${ }^{d}$ SDA - sequential deletion analysis, iterative sequential deletion of one dose (or concentration) of a drug at a time for repetitive CI calculations; ${ }^{\mathrm{C}} \mathrm{DRI}-$ dose reduction index shows the extent that the dose of each drug in a synergistic combination can be reduced at a given effect level compared with the doses of each sample alone; LeuA-L. europaeus A; LeuB-L.europaeus B; LeuC-L. europaeus C; Lex-L. exaltatus; LGlr-luteolin-7-O-glucuronide; RA-rosmarinic acid.

DRI values for all tested combinations were higher than 1 . This means that the concentration of the samples can be reduced when using the weight equivalent mixtures to achieve the same effect compared to the single-drug treatment. For example, the dose of LGlr can be reduced 5.38 times and RA can be reduced 1.61 times, respectively, when tested in their mixture in the ABTS assay to achieve the same effect as if each compound was used separately. In the latter case, we would need $7.37 \mu \mathrm{g} / \mathrm{mL}$ 
of LGlr or $2.20 \mu \mathrm{g} / \mathrm{mL}$ of RA; however, when combined together, we need only $1.37 \mu \mathrm{g} / \mathrm{mL}$ each to achieve the effect of a single agent. A significant dose decrease of Lycopus leaf infusion is also present in all assays when combined with RA and LGlr. In the ABTS assay, we can reduce the dose of LeuB, RA, and LGlr 7.74 times, 1.95 times, and 6.52 times, respectively. It is more effective to use this triple combination, because to achieve the same effect we needed only $1.13 \mu \mathrm{g} / \mathrm{mL}$ of LeuB, RA, and LGlr; on the other hand, when used alone we need $8.75 \mu \mathrm{g} / \mathrm{mL}$ of LeuB, $2.20 \mu \mathrm{g} / \mathrm{mL}$ of RA, and $7.37 \mu \mathrm{g} / \mathrm{mL}$ of LGlr. Similar dose reduction also occurs in DCFH-DA and DPPH assays. The DCFH-DA assay showed the biggest dose reduction. We needed only $0.19 \mu \mathrm{g} / \mathrm{mL}$ of Lex, RA, and LGlr, as opposed to $2.17 \mu \mathrm{g} / \mathrm{mL}$ of Lex, $0.94 \mu \mathrm{g} / \mathrm{mL}$ of LGlr, and $0.63 \mu \mathrm{g} / \mathrm{mL}$ of RA to achieve the same effect.

\section{Discussion}

Until today, a few studies were published about biological activities of species from the genus Lycopus. This was one of the reasons why we have chosen to examine different taxa of Lycopus with origins in Central Europe. We analyzed and tested infusions (water extract), the most common form of usage of medicinal plants as remedies in traditional medicine.

Using the LC-MS-DAD (Liquid Chromatography Mass Spectrometry and Diode Array Detection) we revealed the presence of thirteen phenolic compounds and quantified them. There were two compounds with dominant amounts in all infusions: rosmarinic acid $(202-237 \mu \mathrm{g} / \mathrm{mL})$ and luteolin-7-O-glucuronide (279-449 $\mu \mathrm{g} / \mathrm{mL})$. Many of the identified compounds were also detected in $L$. europaeus in the past [13]. Next, we looked for the disparities between three genotypes of L. europaeus and between different species. We did not detect a high variability in the composition of different genotypes of Lycopus between either species, namely L. europaeus and L. exaltatus, which can also be seen in our results of bioactivities.

The emergence and spread of resistance to antibiotics, as well as the evolution of new strains of disease-causing agents, represent the main factors justifying the need to find and develop new antimicrobial agents. New sources, especially plant sources, are, thus, being investigated. Secondary metabolites form the defense system in plants, which fights against predators such as herbivores, insects, and microorganisms. These substances may act through different mechanisms than conventional antibiotics, and thus they can be utilized in the treatment of infections caused by resistant bacteria. These mechanisms include inhibition of synthesis of nucleic acids, direct interaction with the cell membrane structures of bacteria, which lead to their damage, inhibitory effects on electron transport in the bacterial respiratory chain, and quorum sensing inhibition $[25,26]$. Several studies on the antimicrobial activity of L. europaeus extracts or isolated compounds of several microbial species have been published in the past. They examined both Gram-positive and Gram-negative bacteria as target microorganisms [12-15]. Gibbons et al. [14] studied an extract and isolated isopimarane diterpenes from L. europaeus. None of the tested diterpenes displayed any antibacterial activity, but in combination with tetracycline and erythromycin, a two-fold reduction of the minimal inhibitory concentrations of these antibiotics against two strains of methicillin-resistant $S$. aureus, possessing multidrug resistance efflux pumps, was observed. Radulović et al. [15] isolated a new abietane-type diterpenoid named euroabienol from L. europaeus fruits and tested its antimicrobial activity against fifteen strains of bacteria. Euroabienol was most active against $S$. aureus and least active against $E$. coli. On the other hand, L. europaeus essential oil, studied by Radulović et al. [12], possessed selectivity towards two Gram-negative strains-E. coli and K. pneumoniae. Fialová et al. [13] tested the antibacterial activity of $L$. europaeus leaf infusion on Staphylococcus aureus clinical strains from catheter-related and skin infections. The infusion showed bactericidal activity at concentrations ranging from 2.5 to $5 \mathrm{mg} / \mathrm{mL}$, without respect to the antimicrobial susceptibility patterns of the tested strains. However, the antimicrobial activity of L. exaltatus has not been tested yet. In our study, the tested Lycopus infusions were the most active against staphylococci, independently of the antimicrobial susceptibility or the clonal characteristics of the strains. The most susceptible Gram-negative bacterial species was Proteus mirabilis. Against the other tested Gram-negative collection strains, as well as the strain of Enterococcus faecalis 
and Candida albicans, the examined Lycopus infusions were active only at concentrations $>10 \mathrm{mg} / \mathrm{mL}$ (or were ineffective in the used concentration range). Differences in the susceptibility of various bacterial species were probably based on the well-known differences in their cell walls, such as different permeability due to the different structures of Gram-positive and Gram-negative bacterial cell walls, the charge of the lipopolysaccharide molecules in the Gram-negative cell walls (e.g., Proteus spp. versus the majority of the other Gram-negative bacteria), or an insufficient redox potential on the cytoplasmic membrane in Enterococcus spp. The reason for the resistance of the tested Candida albicans strains might be their similar origin (impermeable cell wall). However, we have not evaluated the interaction of the individual secondary metabolites contained in the Lycopus infusions with the cell walls of the mentioned microbes. Concerning the antibacterial activity of the examined Lycopus infusions, we suggest that it could be bound to the presence of RA, which even in solo has excellent antimicrobial activity [27-30]. To equalize the activity of tested infusions and solo RA, we had to triple or even quadruple the doses of infusions [29]. Taking into account the MIC and MBC values of tested Lycopus infusions for the bacterial strains used in the study, the infusions might be effective in the treatment of local infections. $\mathrm{Tt}$ is known that the application of topical remedies enables an immediate contact of active compounds at rather high concentrations with the microorganisms present in the infectious focus.

Antioxidants have proven beneficial effects on health. There are many studies confirming their ability to prevent diseases, including cancer, neurodegenerative, autoimmune, or cardiovascular diseases [31-34]. Among different secondary plant metabolites, phenolics and flavonoids are the main compounds with considerable antioxidant activity [35-37]. Lycopus spp. contains a high amount of phenolics and flavonoids; therefore, it is a perspective genus possessing antioxidant properties. Antioxidant activities of different Lycopus spp., including L. europaeus, were previously published [13,38,39], but the activity of L. exaltatus leaf infusion was explored for the first time. For antioxidant activity evaluation, we used DPPH and ABTS in vitro scavenging assays. Both 2,2-diphenyl-1-picrylhydrazyl (DPPH) and 2,2' -azino-bis(3-ethylbenzothiazoline-6-sulfonic acid) diammonium salt (ABTS) are well-known radicals and radical precursors. They are active in assays based on electron transfer in the protic solvent [40]. We used DCFH-DA on NIH-3T3 cell line for the evaluation of intracellular oxidative stress inhibition by plant infusions. Some external antioxidants could help intracellular antioxidant systems to reduce the damage due to free radicals and reactive oxygen species (ROS). In the chosen method, we used the fluorescence-based indicator DCFH-DA [41,42]. As a generator of oxidative stress, we used $\mathrm{H}_{2} \mathrm{O}_{2}$ and we studied the inhibition of artificially created oxidative stress in the presence of plant samples.

The free radical scavenging activity of Lycopus infusions might be related to the content of phenolics, where RA and LGlr were detected as the most abundant ones. Phenolic compounds can easily donate electrons to reactive radicals as $\mathrm{DPPH}^{\bullet}$ or $\mathrm{ABTS}^{\bullet+}$. RA is a well-known antioxidant and there are many studies that confirm its effects [43-46]. Luteolin is also known for its antioxidant activity [47]. According to literature, glycosylation of flavonoids reduces their antioxidant activity when compared to the corresponding aglycones [48]. One study compared the antioxidant activity of RA and LGlr using DPPH assay. The antioxidant activity of RA was a few times higher than the effect of LGIr [49], which corresponds to our results. Our results showed that RA is more than three times more effective than LGIr ( $\mathrm{IC}_{50} 2.20 \mu \mathrm{g} / \mathrm{mL}$ and $7.37 \mu \mathrm{g} / \mathrm{mL}$, respectively) using ABTS assay. LeuB has the highest amount of RA $(237.5 \pm 0.8 \mu \mathrm{g} / \mathrm{mL})$ and is also the most effective sample in this method (IC $508.75 \mu \mathrm{g} / \mathrm{mL}$ ). In DCFH-DA and DPPH assays ( $\mathrm{IC}_{50} 0.63 \mu \mathrm{g} / \mathrm{mL}$ and $1.81 \mu \mathrm{g} / \mathrm{mL}$, respectively), RA is only 1.5 and 1.8 times more effective than LGlr ( $\mathrm{IC}_{50} 0.94 \mu \mathrm{g} / \mathrm{mL}$ and $3.29 \mu \mathrm{g} / \mathrm{mL}$, respectively). Therefore, we suppose that samples with a noticeably higher amount of LGlr probably possess higher antioxidant activity than other samples. Only one sample (Lex) had a comparable amount of RA as the other samples $(216.2 \pm 0.1 \mu \mathrm{g} / \mathrm{mL})$, but 1.6 times more LGlr $(449.8 \pm 0.4 \mu \mathrm{g} / \mathrm{mL})$ than LeuB, which was the most effective sample in the ABTS assay. This could be the reason why Lex was the most effective sample in DCFH-DA and DPPH assays ( $\mathrm{IC}_{50}$ values of $2.17 \mu \mathrm{g} / \mathrm{mL}$ and $8.30 \mu \mathrm{g} / \mathrm{mL}$, respectively). The second highest amount of LGlr was found in L. europaeus (LeuA), which was 
the second most effective sample in DCFH-DA and DPPH assays ( $\mathrm{IC}_{50}$ values of $2.64 \mu \mathrm{g} / \mathrm{mL}$ and $8.42 \mu \mathrm{g} / \mathrm{mL}$, respectively).

Diverse secondary metabolites are present in plants. This heterogeneity assumes a high likelihood of interactions among molecules. Because the mode of action of complex mixtures (including the derivatives from plants) cannot be attributed to a single compound in most cases, interaction analysis, which evaluates the character of the mutual reaction, is necessary. Synergy or antagonism is present if the effect of a sample combination is greater or lesser than from the dose-effect relationships of single agents (i.e., additivity). Because of its complexity, the synergy study has become a key area in phytomedicine research in recent years [40]. For the interaction evaluation, the combination index derived by Chou was used [24]. We applied an interaction analysis between RA and LGlr using ABTS, $\mathrm{DPPH}$, and DCFH-DA assays for the first time. RA and luteolin acted synergistically when testing anti-inflammatory activity in lipopolysaccharide-stimulated RAW 264.7 macrophage cells [50], so there was a chance they might also act synergistically in our models. In our study, the combination of RA and LGlr showed moderate synergism in all assays. In all cases (tested combinations) we detected a synergistic or nearly additive effect, which may support preferable usage of mixtures and combinations for the future.

\section{Materials and Methods}

\subsection{Plant Material}

Aerial parts of the three genotypes of L.europaeus, namely L. europaeus A (LeuA), L. europaeus B (LeuB), and L. europaeus C (LeuC), and one genotype of L. exaltatus (Lex), were collected in July during sunny weather. The plants were picked up from different places, as shown in Table 6 . The harvested plants (about 20-30 individuals) were 1 year old and all of them were collected during their flowering time. The plants were dried at room temperature $\left(25^{\circ} \mathrm{C}\right)$ in shade. The leaves were separated from the stems and flowers.

Table 6. The harvest locations of plants.

\begin{tabular}{clll}
\hline & Latitude & Longitude & Elevation $(\mathrm{m})$ \\
\hline LeuA & $50^{\circ} 52^{\prime} 30,8^{\prime \prime}$ & $14^{\circ} 28^{\prime} 18,1^{\prime \prime}$ & 380 \\
LeuB & $49^{\circ} 04^{\prime} 39.5^{\prime \prime}$ & $14^{\circ} 20^{\prime} 45.9^{\prime \prime}$ & 342 \\
LeuC & $46^{\circ} 07^{\prime} 51.42^{\prime \prime}$ & $17^{\circ} 56^{\prime} 12.3^{\prime \prime}$ & 174 \\
Lex & $47^{\circ} 54^{\prime} 27.00^{\prime \prime}$ & $20^{\circ} 19^{\prime} 19.44^{\prime \prime}$ & 324 \\
\hline LeuA-L. europaeus A; LeuB-L. europaeus B; LeuC-L. europaeus C; Lex-L. exaltatus.
\end{tabular}

\subsection{The Preparation of Infusions}

The infusions were prepared according to the article "Decocta Infusa" in the Czech-Slovak Pharmacopoeia, 4th edition [51], as follows: $15 \mathrm{~g}$ of leaves were macerated in $150 \mathrm{~mL}$ of boiling deionized water for $5 \mathrm{~min}$ and then cooled at room temperature for $45 \mathrm{~min}$. The obtained infusion was filtered, frozen, and lyophilized. The yields of infusions were $21.33 \%$ for LeuA, $19.77 \%$ for LeuB, $17.29 \%$ for LeuC, and $20.34 \%$ for Lex.

\subsection{LC-MS-DAD Analyses: Identification and Quantification of the Constituents}

The LC-MS-DAD analyses of four samples of Lycopus leaf infusions were performed on an Agilent 1260 Infinity LC System (Agilent Technologies, Santa Clara, CA, USA), equipped with a binary pump, an autosampler, a column thermostat, and a diode array detector (DAD), coupled to a quadrupole-time-of-flight (6520 Accurate-Mass QTOF) instrument equipped with an orthogonal electrospray ionisation source (ESI) (Agilent Technologies, Santa Clara, CA, USA). The separation of Lycopus infusions was carried out on a Kromasil C18 column $(150 \mathrm{~mm} \times 4.6 \mathrm{~mm}, 5 \mu \mathrm{m}$, Sigma-Aldrich, 
Munich, Germany) at $35^{\circ} \mathrm{C}$ and a flow rate of $0.4 \mathrm{~mL} / \mathrm{min}$. Deionized water (adjusted to $\mathrm{pH} 3.1$ with $\mathrm{HCOOH} / \mathrm{NH}_{4} \mathrm{HCO}_{3}$ ) and acetonitrile were used as mobile phases $\mathrm{A}$ and $\mathrm{B}$, respectively. The following gradient program was used: 5\% B (0 min), 20\% B (20 min), 20\% B (25 min), 40\% B (40 min), 50\% B (60 $\mathrm{min}), 65 \%$ B (65 min), 100\% B (90 $\mathrm{min}), 100 \%$ (95 min), and 5\% (96 min). The ESI ion source parameters were as follows: capillary voltage: $3.5 \mathrm{kV}$; nebulizer: $40 \mathrm{psi}\left(\mathrm{N}_{2}\right)$; dry gas flow: $10 \mathrm{~L} / \mathrm{min}$ $\left(\mathrm{N}_{2}\right)$; and dry temperature: $300{ }^{\circ} \mathrm{C}$. The mass spectrometer was operated in an auto $\mathrm{MS}^{2}$ mode, where each negative ion MS scan ( $\mathrm{m} / \mathrm{z}$ 100-3000, average of four spectra) was followed by $\mathrm{MS}^{2}$ scans $(\mathrm{m} / \mathrm{z}$ 100-3000, average of four spectra, isolation window of $4 \mathrm{amu}$, collision energy $20 \mathrm{eV})$ of the two most intense precursor ions. Ions were excluded from analyses for $0.5 \mathrm{~min}$ after two $\mathrm{MS}^{2}$ spectra had been acquired. Nitrogen was used as the collision gas. Phenolic compounds were identified by comparing their UV and mass spectra with literature and authentic standards when available and by measuring accurate $\mathrm{m} / \mathrm{z}$ values.

The quantitative determination of phenolic compounds in Lycopus leaf infusions was performed by the method of external standards. The HPLC-DAD (High-Performance Liquid Chromatography with a Diode-Array Detector) chromatograms were acquired at two wavelengths of $320 \mathrm{~nm}$ and $360 \mathrm{~nm}$, respectively. The standard of RA (purity 96\%, Sigma-Aldrich, St. Louis, MO, USA) was used for quantification of phenolic acids and their derivatives $(\lambda=320 \mathrm{~nm})$ and LGlr (primary RS, purity $>$ $95 \%$, Sigma Aldrich St. Louis, MO, USA) was used as a standard for quantification of flavonoids and their glycosides $(\lambda=360 \mathrm{~nm}$ ) (see Table 1). The examinations of secondary metabolites in Lycopus leaf infusions were performed in triplicate. The quantitative results were calculated from calibration curves, expressed as mean values and standard deviation (SD).

\subsection{Antimicrobial Activity Testing}

Seven bacterial collection strains (Staphylococcus aureus CCM 4223, Staphylococcus aureus CCM 4750, Enterococcus faecalis CCM 4224, Pseudomonas aeruginosa CCM 3955, Escherichia coli CCM 3954, Klebsiella pneumoniae CCM 4415, Proteus mirabilis CCM 7188), one collection strain of Candida albicans (CCM 90028), and 28 clinical S. aureus strains were used in the study. The collections strains were purchased from the Czech Collection of Microorganisms, Brno, Czech Republic (for more detailed characteristics, see Table 7); the clinical strains were isolated from infections of patients hospitalized at the University Hospital in Bratislava, Slovakia. Nineteen strains originated from infections associated with skin, soft tissue, or wounds, and 9 strains came from bloodstream infections (Table 8).

Table 7. The tested bacterial collection strains.

\begin{tabular}{lcl}
\hline \multicolumn{1}{c}{ Bacterial Species } & The CCM / ATCC No of Strain & \multicolumn{1}{c}{ Note } \\
\hline Staphylococcus aureus & CCM 4223 / ATCC 29213 & MSSA; ATM susceptibility QC strain \\
Staphylococcus aureus & CCM 4750 / ATCC 43300 & MRSA; methicillin susceptibility reference strain \\
Enterococcus faecalis & CCM 4224 / ATCC 29212 & ATM susceptibility QC strain \\
Pseudomonas aeruginosa & CCM 3955 / ATCC 27853 & ATM susceptibility QC strain \\
Escherichia coli & CCM 3954 / ATCC 25922 & ATM susceptibility QC strain \\
Klebsiella pneumoniae & CCM 4415 / ATCC 10031 & ATM susceptibility QC strain \\
Proteus mirabilis & CCM 7188 / ATCC 29906 & Assays of ATM preservative QC \\
\hline
\end{tabular}

Note: ATM-antimicrobial; QC—quality control; CCM-Czech Collection of Microorganisms; ATCC—American Type Culture Collection. 
Table 8. The tested clinical Staphylococcus aureus strains.

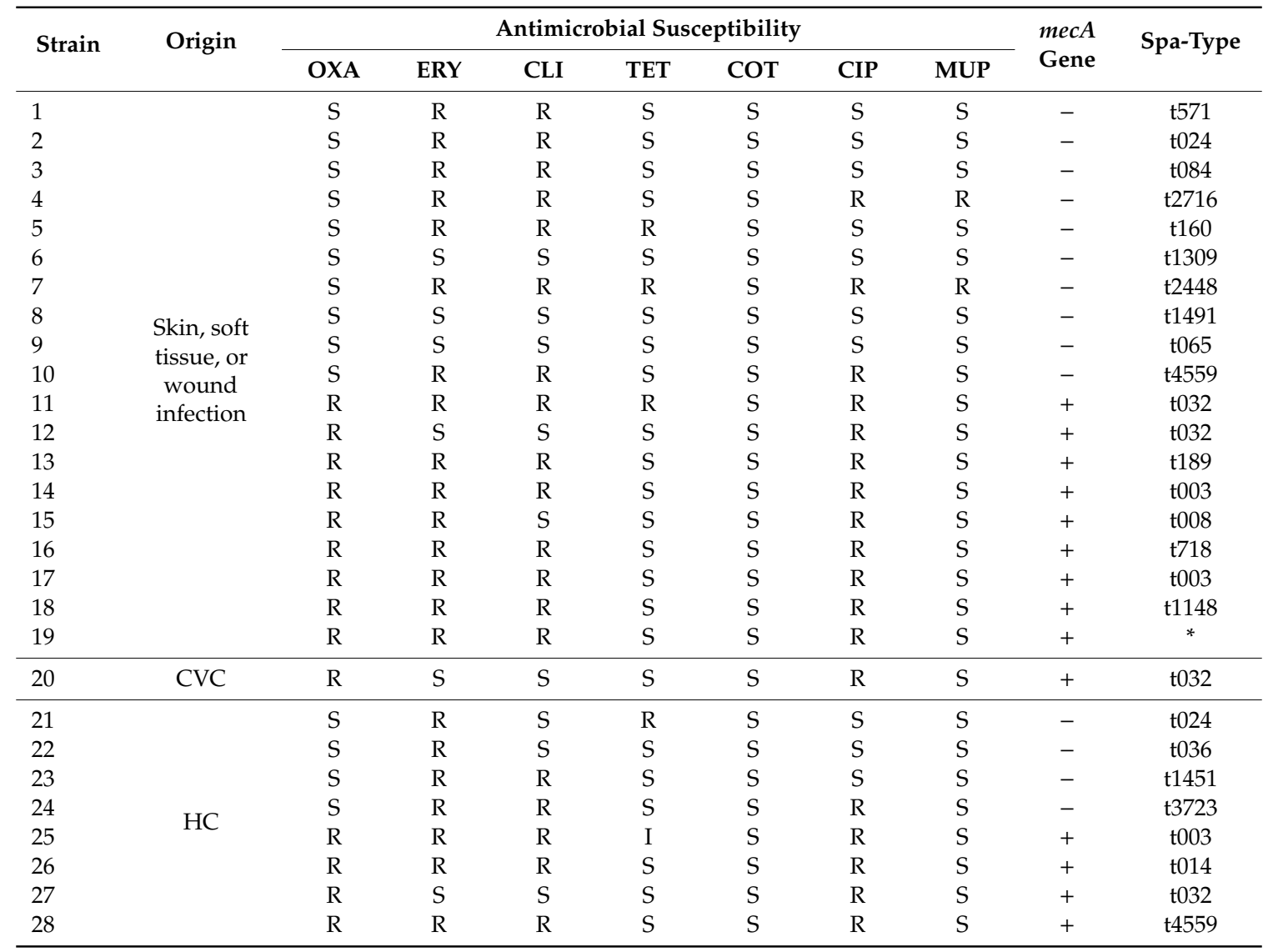

Note: CVC—central venous catheter; HC—hemoculture; OXA-oxacillin; ERY-erythromycin; CLI-clindamycin; TET-tetracycline; COT-cotrimoxazole; CIP—ciprofloxacin; MUP-mupirocin; mecA gene coding for PBP2a protein, responsible for methicillin resistance in staphylococci; +-positive; ${ }^{*}$ new spa type, uploaded to the international database and waiting for t-number assignment; S-susceptible, standard dosing regimen; R-resistant; I-susceptible, increased exposure; the corresponding MIC values are included in Table 9.

Table 9. The MIC values corresponding to the susceptibility categories ( $\mathrm{S}$ and $\mathrm{R}$ ) of the tested antibiotics, based on the EUCAST (The European Committee on Antimicrobial Susceptibility Testing) clinical break-points [52].

\begin{tabular}{ccc}
\hline Antibiotic & Susceptible [mg/L] & Resistant [mg/L] \\
\hline Oxacillin & $<2$ & $>2$ \\
Erythromycin & $\leq 1$ & $>2$ \\
Clindamycin & $\leq 0.25$ & $>0.5$ \\
Tetracycline & $\leq 1$ & $>2$ \\
Cotrimoxazole & $\leq 2$ & $>4$ \\
Ciprofloxacin & $\leq 0.001$ & $>1$ \\
Mupirocin & $\leq 1$ & NA \\
\hline
\end{tabular}

NA-not applicable; only screening.

The antimicrobial susceptibility of clinical S. aureus strains was detected in oxacillin, erythromycin, clindamycin, tetracycline, cotrimoxazole, ciprofloxacin, and mupirocin, using the disk diffusion method according to the EUCAST recommendations [52]. For the testing, Mueller-Hinton agar (OXOID, Great Britain) and commercial antibiotic disks (OXOID, Great Britain) were used. Resistance to methicillin or oxacillin was confirmed by penicillin binding protein 2a latex agglutination test (MRSA-screen, Denka Seiken Co, Japan) and by PCR (Polymerase Chain Reaction) for mecA gene detection [53]. Spa typing was performed according to Ridom Bioinformatics [54]. PCR products were purified by illustra ${ }^{\mathrm{TM}}$ ExoProStar ${ }^{\mathrm{TM}}$ (GE Healthcare, Chicago, IL, United States). The PCR amplicons 
were sequenced by BigDye Terminator v3.1 Cycle Sequencing Kit (Applied Biosystems, Foster City, CA, USA) and sequencing was carried out on ABI PRISM 3130xl Genetic Analyser (Applied Biosystems, Foster City, CA, USA). DNA sequences were analyzed with BioNumerics software (Applied Maths, Sint-Martens-Latem, Belgium).

The minimal inhibitory (MIC) and minimal bactericidal concentrations (MBC) of plant material infusions were tested by broth microdilution assay according to the EUCAST recommendations [52]. For antimicrobial activity testing, the lyophilized plant infusions were dissolved in sterile Aqua Pro Injection and filtration-sterilized (Merck Millipore Ltd., Ireland). The testing was performed in U-shaped, sterile 96-well microtiter plates (Roll s.a.s., Piove di Sacco, Italy). The samples in the working concentration were added to the starting wells with a double concentrated antibiotic susceptibility testing medium (Mueller-Hinton Broth, OXOID Ltd., Basingstoke, UK). Afterward, serial geometric dilutions from 0.3125 to $5 \mathrm{mg} / \mathrm{mL}$ were prepared in the final volume of $100 \mu \mathrm{L}$. Bacterial inoculum was prepared from a culture grown overnight on blood agar. Well-isolated colonies were suspended in sterile physiologic solution and the suspension was adjusted to contain $1 \times 10^{6} \mathrm{CFU} / \mathrm{mL}$. The standardized suspensions of microorganisms were added to each well in $10 \mu \mathrm{L}$ aliquots (except for the sterility control wells, i.e., negative controls) and incubated for $24 \mathrm{~h}$ at $35^{\circ} \mathrm{C}$. Wells with microorganisms in the medium free of the tested agent were used as growth control (positive controls). MIC was determined as the lowest concentration of antimicrobial agent that completely inhibited the growth of the tested microorganisms, detected by the unaided eye. MBCs were determined by sub-culturing the samples from wells yielding a negative microbial growth. After their overnight incubation at $35^{\circ} \mathrm{C}$ on the agar medium free of antimicrobial agents, the MBCs were determined as the lowest concentration at which $99.9 \%$ of the tested microbial inoculum was killed.

The activity of the plant infusions on yeast Candida albicans was tested by a modified broth microdilution test according to the Clinical and Laboratory Standards Institute document M27-A1 [55]. Then, $100 \mu \mathrm{L}$ aliquots of yeast cell suspension in physiologic saline, prepared from $24 \mathrm{~h}$ culture grown aerobically on Sabouraud agar (BD, Sparks, MD, USA), were added to the samples of 2-fold-concentrated tested plant infusions in $100 \mu \mathrm{L}$ volume of Sabouraud-broth-modified antibiotic medium 13 (BD, Sparks, MD, USA) in the U-shaped microtiter plate wells. The final concentration of the yeast cells in each well was $1 \times 10^{4}$ yeasts $/ \mathrm{mL}$. Microtiter plates were incubated at $35^{\circ} \mathrm{C}$ for $48 \mathrm{~h}$ aerobically. Samples without yeasts and without tested plant infusions were run in each test plate. The MICs and MBCs were determined using the method described in susceptibility testing of bacterial strains.

All MIC and MBC tests were performed in three independent runs.

\subsection{Evaluation of Antioxidant Activity}

\subsubsection{DPPH Radical Scavenging Assay}

Total free radical scavenging capacity of the infusions from different plant samples was estimated spectrophotometrically using the stable 2,2-diphenyl-1-picrylhydrazyl radical (DPPH, Sigma-Aldrich, St. Louis, MO, USA), which has an absorption maximum at $515 \mathrm{~nm}$ [56]. A solution of the radical was prepared by dissolving $4.4 \mathrm{mg}$ DPPH in $200 \mathrm{~mL}$ distilled methanol. Lyophilized plants were dissolved in deionized water in various concentrations, while RA and LGlr were dissolved in distilled ethanol. Here, $25 \mu \mathrm{L}$ of the samples and $225 \mu \mathrm{L}$ of DPPH solution were added to 96-well Greiner UV star microplates (Greiner-Bio One $\mathrm{GmbH}$, Frickenhausen, Germany) and mixed. Absorbance was measured after $30 \mathrm{~min}$ at the wavelength of $515 \mathrm{~nm}$ using an Infinite M200 microplate reader (Tecan AG, Grödig, Austria) and compared to a blank. The capability to scavenge the DPPH radical was calculated using Equation (1):

$$
\text { DPPH scavenging effect }(\%)=\left(\frac{A_{B}-A_{A}}{A_{B}}\right) \times 100
$$


where $A_{B}$ is the absorbance of blank and $A_{A}$ is the absorbance of the sample. The antioxidant activity of plant infusions was tested in quadruplicate and compared with RA, which was used as positive control.

\subsubsection{ABTS Radical Scavenging Assay}

The free radical scavenging activity of plant samples was determined spectrophotometrically by the ABTS decolorization assay [57]. ABTS radical cations were produced via the reaction of $7 \mathrm{mM}$ water solution of ABTS (purity $\geq 98 \%$, Sigma-Aldrich, St. Louis, MO, USA) with $2.45 \mathrm{mM}$ water solution of potassium persulfate (purity $\geq 99.0$, Sigma-Aldrich, St. Louis, MO, USA) (1:1, V/V), then stored in the dark at room temperature for $16-24 \mathrm{~h}$ before use. Then, $1.1 \mathrm{~mL}$ of the ABTS radical cation solution was then diluted with distilled ethanol to obtain the final volume of $50 \mathrm{~mL}$. Plant lyophilisates were dissolved in deionized water, while RA and LGlr were dissolved in distilled ethanol in various concentrations. Here, $2.5 \mu \mathrm{L}$ of samples and $247.5 \mu \mathrm{L}$ of diluted ABTS radical cation solution were added to 96-well Greiner UV star microplates (Greiner-Bio One GmbH, Frickenhausen, Germany) and mixed. Absorbance was measured after $6 \mathrm{~min}$ at a $734 \mathrm{~nm}$ wavelength using an Infinite M200 microplate reader (Tecan AG, Grödig, Austria) and compared to a blank. Percent inhibition of absorbance at $734 \mathrm{~nm}$ was calculated using Equation (2):

$$
\text { ABTS scavenging effect }(\%)=\left(\frac{A_{B}-A_{A}}{A_{B}}\right) \times 100
$$

where $A_{B}$ is the absorbance of the ABTS radical cation + ethanol, while $A_{A}$ is the absorbance of the ABTS radical cation + sample. The antioxidant activity measurements of plant infusions were performed in quadruplicate and compared with RA, which was used as positive control.

\subsubsection{Detection of Intracellular Oxidative Stress}

NIH-3T3 cells (mouse embryonic fibroblasts) were obtained from the Department of Pharmacology and Toxicology, Faculty of Pharmacy, Comenius University in Bratislava, Slovakia. The cells were grown in DMEM (Sigma-Aldrich, St. Louis, MO, USA) supplemented with 10\% FBS (Sigma-Aldrich, St. Louis, MO, USA), $100 \mu \mathrm{g} / \mathrm{mL}$ streptomycin (Sigma-Aldrich, St. Louis, MO, USA), and $100 \mathrm{IU} / \mathrm{mL}$ penicillin (Sigma-Aldrich, St. Louis, MO, USA) at $37^{\circ} \mathrm{C}$ in a humidified atmosphere with $5 \% \mathrm{CO}_{2}$. The cells were sub-cultured twice a week. Detection of oxidative stress with DCFH-DA was determined according to Miranda-Rottmann et al. [58] with slight modifications. The ROS generation was measured using the fluorescence-based indicator, dichlorodihydrofluorescein diacetate (DCFH-DA, purity $\geq$ 97\%, Sigma-Aldrich, St. Louis, MO, USA). The non-ionic DCFH-DA crosses the cell membrane and is hydrolyzed to nonfluorescent DCFH by intracellular esterases. In the presence of ROS, such as hydrogen peroxide, DCFH is rapidly oxidized to fluorescent dichlorofluorescein (DCF), which can be detected using a sensitive fluorescence spectrophotometer. The fluorescence intensity reflects the amount of intracellular ROS formed [59]. The 3T3 cells were seeded in the black 96-well plates (Sarstedt, Nümbrecht, Germany) at 15,000 cells/100 uL/well. After $24 \mathrm{~h}$ incubation, the medium was removed and replaced by the serum-free medium (Sigma-Aldrich, St. Louis, MO, USA). After $1 \mathrm{~h}$ incubation, $5 \mu \mathrm{l}$ of the tested infusions (RA and LGlr) in various concentrations were added. The tested samples were dissolved in the serum-free medium. After $1 \mathrm{~h}$, DCFH-DA was added (10 $\mu \mathrm{M}$ in final concentration). After $15 \mathrm{~min}, \mathrm{H}_{2} \mathrm{O}_{2}$ (Sigma-Aldrich, St. Louis, MO, USA) was added ( $100 \mu \mathrm{M}$ in final concentration). The intracellular fluorescence of DCF was measured by excitation and emission at 480 and $530 \mathrm{~nm}$, and compared to a blank after $15 \mathrm{~min}$ in an Infinite M200 microplate reader (Tecan AG, Grödig, Austria). All measurements were performed in quadruplicate and compared with RA. 


\subsection{Interaction Analysis of Antioxidant Activities}

For quantitative determination of drug interactions, combination index (CI) derived by Chou was used, where $\mathrm{CI}<1,=1$, and $>1$ indicate synergism, additive effect, and antagonism, respectively [24]. Equation (3) shows the general equation for an $\mathrm{n}$-drug combination at $\mathrm{x} \%$ inhibition:

$$
{ }^{n}(C I)_{x}=\sum_{j=1}^{n}(D)_{j} /\left(D_{x}\right)_{j}
$$

where ${ }^{n}(C I)_{x}$ is the combination index for $n$ drugs that exerts $x \%$ inhibition, $\left(D_{x}\right)$ is a dose "alone" that exerts $\mathrm{x} \%$ inhibition, and $\mathrm{D}$ is a dose "in combination" that inhibits a system by $\mathrm{x} \%$.

Using the CI grading system, synergism and antagonism were subdivided by Chou [24] into 11 ranges, as seen in Table 10.

Table 10. The scales of combined effects using the CI grading.

\begin{tabular}{cc}
\hline Range of Combination Index & Description \\
\hline$<0.1$ & Very strong synergism \\
$0.1-0.3$ & Strong synergism \\
$0.3-0.7$ & Synergism \\
$0.7-0.85$ & Moderate synergism \\
$0.85-0.90$ & Slight synergism \\
$0.90-1.10$ & Nearly additive \\
$1.10-1.20$ & Slight antagonism \\
$1.20-1.45$ & Moderate antagonism \\
$1.45-3.3$ & Antagonism \\
$3.3-10$ & Strong antagonism \\
$>10$ & Very strong antagonism \\
\hline
\end{tabular}

One of the major objectives of using synergistic drug combinations is the reduction of the dose of the drugs needed to achieve the same effect. The dose reduction index (DRI) shows how much the dose of each drug in a synergistic combination can be reduced at a given effect level compared with the doses of each drug alone. The DRI is important in clinical situations, in which dose reduction leads to reduced toxicity, while the effect remains the same [24]. The calculation of DRI is shown in Equation (4):

$$
(D R I)_{1}=\frac{\left(D_{x}\right)_{1}}{(D)_{1}} ;(D R I)_{2}=\frac{\left(D_{x}\right)_{2}}{(D)_{2}} \ldots \text { etc. }
$$

The value of DRI $>1$ is beneficial because it indicates a dose reduction but does not necessarily always indicate synergism. The greater the DRI value, the higher the dose reduction for a given therapeutic effect. Both CI and DRI, as well as concentration leading to 50\% inhibition (IC 50 ), were calculated using a median effect analysis by CompuSyn software (version 1.0.1, ComboSyn Inc., Paramus, NJ, USA). For the analysis, we chose the most effective sample in each assay (ABTS, DPPH, and DCFH-DA) and combined it with RA or LGlr (1:1 $\mu \mathrm{g})$. We also tested a weight equivalent combination of RA and LGlr and their triple combination with the Lycopus leaf infusions. We did not test equimolar concentrations of RA and LGlr because we did not know the molar weights of lyophilisates. We used the same solutions in all experiments, so we chose the weight equivalent concentration.

\section{Conclusions}

Plants from the genus Lycopus may be considered as valuable antioxidant and antimicrobial agents. This study shows that the antioxidant activity of Lycopus infusions expressed as $\mathrm{IC}_{50}$ is lower than $10 \mu \mathrm{g} / \mathrm{mL}$, which means a high antioxidant efficacy, especially for L. exaltatus, the antioxidant activity of which was studied for the first time. Furthermore, we detected a moderate 
synergistic effect between the most abundant compounds of infusion, namely rosmarinic acid and luteolin-7-O-glucuronide. A synergistic effect also occurs in the combination of infusion and rosmarinic acid or luteolin-7-O-glucuronide, respectively, and their triple combination. This interaction study, performed with Lycopus for the first time, reveals a high dose reduction index, which may lead to the possible use of lower doses of substances in combination in comparison to the doses of single substances. Lycopus infusions were also effective against diverse clinical Staphylococcus aureus strains with varying antimicrobial susceptibility, including methicillin-resistant ones. All these results suggest that the plants of the genus Lycopus will play an important role as promising antioxidants and antimicrobial agents in the future, especially in the treatment of local staphylococcal infections.

Author Contributions: Conceptualization, E.T., S.B.F., and L.S.; plant material selection, I.Č.; experiments, methodology, and data curation, E.T., S.B.F., L.S., S.D., M.S., and A.L., funding acquisition, S.B.F., P.M., and M.N.; project administration, S.B.F., E.T., and L.S.; writing-original draft, E.T., S.B.F., L.S., and E.K.; supervision, S.B.F., P.M., M.N., and L.S. All authors have read and agreed to the published version of the manuscript.

Funding: This work was supported by the Grant Agency of Ministry of Education, Science, Research, and Sport of Slovakia (grant no. VEGA-1/0284/20) and by the Slovak Research and Development Agency under contract numbers APVV-15-0123 and APVV-17-0281.

Acknowledgments: The authors would like to thank to Diana Vavrincová (Department of Pharmacology and Toxicology, Faculty of Pharmacy, Comenius University in Bratislava, Slovakia) for NIH/3T3 cells (mouse embryonic fibroblasts).

Conflicts of Interest: The authors declare no conflict of interest.

\section{References}

1. Wagner, H.; Ulrich-Merzenich, G. Synergy research: Approaching a new generation of phytopharmaceuticals. Phytomedicine 2009, 16, 97-110. [CrossRef] [PubMed]

2. Williamson, E. Synergy and other interactions in phytomedicines. Phytomedicine 2001, 8, 401-409. [CrossRef] [PubMed]

3. Ma, X.H.; Zheng, C.J.; Han, L.Y.; Xie, B.; Jia, J.; Cao, Z.W.; Li, Y.X.; Chen, Y.Z. Synergistic therapeutic actions of herbal ingredients and their mechanisms from molecular interaction and network perspectives. Drug Discov. Today 2009, 14, 579-588. [CrossRef] [PubMed]

4. Kurin, E.; Nagy, M. Theoretical Models for Analysis of Syergy and Antagonism of Drugs (Teoretické modely analýzy synergie a antagonizmu liečiv). Chem. Listy 2012, 106, 653-659.

5. Lehár, J.; Krueger, A.; Zimmermann, G.; Borisy, A. High-order combination effects and biological robustness. Mol. Syst. Biol. 2008, 4, 215. [CrossRef] [PubMed]

6. Moon, H.-K.; Hong, S.-P. Nutlet morphology and anatomy of the genus Lycopus (Lamiaceae: Mentheae). J. Plant. Res. 2006, 119, 633-644. [CrossRef] [PubMed]

7. Peng, T.; Yin, Z.; Yang, B.; Kang, W. Research Progress on the Chemical Constituents of Lycopus Genus. Curr. Opin. Complement. Alternat. Med. 2014, 1, 28-33.

8. Moon, H.-K.; Hong, S.-P. Pollen morphology of the genus Lycopus (Lamiaceae). Ann. Bot. Fenn. 2003, 40, 191-198.

9. Hussein, A.A.; Rodríguez, B.; de la Paz Martí-nez-Alcázar, M.; Cano, F.H. Diterpenoids from Lycopus europaeus and Nepeta septemcrenata: Revised Structures and New Isopimarane Derivatives. Tetrahedron 1999, 55, 7375-7388. [CrossRef]

10. Aziz, A.; Khan, I.A.; Perveen, A.; Agha, S.; Munawar, S.H.; Manzoor, Z. Evaluation of antitussive activity of Lycopus europaeus on cough reflex induced by different cough induced models in mice. Int. J. Pharma. Sci. 2013, 3, 381-385.

11. Aziz, A.; Khan, I.A.; Hussain, M.; Afzal, A. Antinociceptive and anti-inflammatory activity of the extract of Lycopus europaes on laboratory animals. Int. J. Res. Dev. Pharm. Life Sci. 2014, 3, 896-904.

12. Radulović, N.; Denić, M.; Stojanović-Radić, Z.; Skropeta, D. Fatty and Volatile Oils of the Gypsywort Lycopus europaeus L. and the Gaussian-Like Distribution of its Wax Alkanes. J. Am. Oil Chem. Soc. 2012, 89, 2165-2185. [CrossRef] 
13. Fialová, S.; Slobodníková, L.; Veizerová, L.; Grančai, D. Lycopus europaeus: Phenolic fingerprint, antioxidant activity and antimicrobial effect on clinical Staphylococcus aureus strains. Nat. Prod. Res. 2015, 29, 2271-2274. [CrossRef]

14. Gibbons, S.; Oluwatuyi, M.; Veitch, N.C.; Gray, A.I. Bacterial resistance modifying agents from Lycopus europaeus. Phytochemistry 2003, 62, 83-87. [CrossRef]

15. Radulović, N.; Denić, M.; Stojanović-Radić, Z. Antimicrobial phenolic abietane diterpene from Lycopus europaeus L. (Lamiaceae). Bioorg. Med. Chem. Lett. 2010, 20, 4988-4991. [CrossRef] [PubMed]

16. Bär, B.; Roesel, R.; Bollbach, D.; Hagels, H.; Langer, E. Wolfstrapp. DAZ 2000, 140, 67-76.

17. Beer, A.-M.; Wiebelitz, K.R.; Schmidt-Gayk, H. Lycopus europaeus (Gypsywort): Effects on the thyroidal parameters and symptoms associated with thyroid function. Phytomedicine 2008, 15, 16-22. [CrossRef] [PubMed]

18. Eiling, R.; Wieland, V.; Niestroj, M. Besserung der Symptome einer leichten Schilddrüsenüberfunktion mit einem Trockenextrakt aus Wolfstrappkraut (Thyreogutt ${ }^{\circledR}$ mono). Wien. Med. Wochenschr. 2013, 163, 95-101. [CrossRef]

19. Vonhoff, C.; Baumgartner, A.; Hegger, M.; Korte, B.; Biller, A.; Winterhoff, H. Extract of Lycopus europaeus L. reduces cardiac signs of hyperthyroidism in rats. Life Sci. 2006, 78, 1063-1070. [CrossRef]

20. Nikpay, A.; Soltani, M. In vitro anti-parasitic activities of Pulicaria dysenterica and Lycopus europaeus methanolic extracts against Trichomonas gallinae. J. Herbmed. Pharmacol. 2018, 7, 112-118. [CrossRef]

21. Henderson, N.C. A Taxonomic Revision of the Genus Lycopus (Labiatae). Am. Midl. Nat. 1962, 68, 95. [CrossRef]

22. Bucar, F.; Kartnig, T. Flavone Glucuronides of Lycopus virginicus. Planta Med. 1995, 61, 378-380. [CrossRef] [PubMed]

23. Miron, T.L.; Herrero, M.; Ibáñez, E. Enrichment of antioxidant compounds from lemon balm (Melissa officinalis) by pressurized liquid extraction and enzyme-assisted extraction. J. Chromatogr. A. 2013, 1288, 1-9. [CrossRef] [PubMed]

24. Chou, T.-C. Theoretical Basis, Experimental Design, and Computerized Simulation of Synergism and Antagonism in Drug Combination Studies. Pharmacol. Rev. 2006, 58, 621-681. [CrossRef]

25. Fialova, S.; Rendekova, K.; Mucaji, P.; Slobodnikova, L. Plant Natural Agents: Polyphenols, Alkaloids and Essential Oils as Perspective Solution of Microbial Resistance. Curr. Org. Chem. 2017, 21. [CrossRef]

26. Lu, L.; Hu, W.; Tian, Z.; Yuan, D.; Yi, G.; Zhou, Y.; Cheng, Q.; Zhu, J.; Li, M. Developing natural products as potential anti-biofilm agents. Chin. Med. 2019, 14, 11. [CrossRef] [PubMed]

27. Ekambaram, S.; Perumal, S.; Balakrishnan, A.; Marappan, N.; Gajendran, S.; Viswanathan, V. Antibacterial synergy between Rosmarinic acid and antibiotics against Methicillin resistant Staphylococcus aureus. J. Intercult. Ethnopharmacol. 2016, 5, 358. [CrossRef]

28. Klančnik, A.; Guzej, B.; Kolar, M.H.; Abramovič, H.; Možina, S.S. In Vitro Antimicrobial and Antioxidant Activity of Commercial Rosemary Extract Formulations. J. Food Prot. 2009, 72, 1744-1752. [CrossRef]

29. Slobodníková, L.; Fialová, S.; Hupková, H.; Grančai, D. Rosmarinic Acid Interaction with Planktonic and Biofilm Staphylococcus aureus. Nat. Prod. Commun. 2013, 8. [CrossRef]

30. Bittner Fialová, S.; Kello, M.; Čoma, M.; Slobodníková, L.; Drobná, E.; Holková, I.; Garajová, M.; Mrva, M.; Zachar, V.; Lukáč, M. Derivatization of Rosmarinic Acid Enhances its in vitro Antitumor, Antimicrobial and Antiprotozoal Properties. Molecules 2019, 24, 1078. [CrossRef]

31. Goszcz, K.; Deakin, S.J.; Duthie, G.G.; Stewart, D.; Leslie, S.J.; Megson, I.L. Antioxidants in Cardiovascular Therapy: Panacea or False Hope? Front. Cardiovasc. Med. 2015, 2, 29. [CrossRef]

32. Khan, M.F.; Wang, G. Environmental agents, oxidative stress and autoimmunity. Curr.Opin. Toxicol. 2018, 7, 22-27. [CrossRef] [PubMed]

33. Leopold, J.A. Antioxidants and coronary artery disease: From pathophysiology to preventive therapy. Coron. Artery Dis. 2015, 26, 176-183. [CrossRef] [PubMed]

34. Singh, N.; Ghosh, K.K. Recent Advances in the Antioxidant Therapies for Alzheimer's Disease: Emphasis on Natural Antioxidants. In Pathology, Prevention and Therapeutics of Neurodegenerative Disease; Singh, S., Joshi, N., Eds.; Springer: Singapore, 2019; pp. 253-263.

35. Croft, K.D. Dietary polyphenols: Antioxidants or not? Arch. Biochem. Biophys. 2016, 595, 120-124. [CrossRef] [PubMed] 
36. Pandey, K.B.; Rizvi, S.I. Plant Polyphenols as Dietary Antioxidants in Human Health and Disease. Oxid. Med. Cell Longev. 2009, 2, 270-278. [CrossRef]

37. Papuc, C.; Goran, G.V.; Predescu, C.N.; Nicorescu, V.; Stefan, G. Plant Polyphenols as Antioxidant and Antibacterial Agents for Shelf-Life Extension of Meat and Meat Products: Classification, Structures, Sources, and Action Mechanisms. Compr. Rev. Food Sci. F. 2017, 16, 1243-1268. [CrossRef]

38. Lu, Y.; Huang, J.; Li, Y.; Ma, T.; Sang, P.; Wang, W.; Gao, C. Variation in nutritional compositions, antioxidant activity and microstructure of Lycopus lucidus Turcz. root at different harvest times. Food Chem. 2015, 183, 91-100. [CrossRef]

39. Ślusarczyk, S.; Hajnos, M.; Skalicka-Woźniak, K.; Matkowski, A. Antioxidant activity of polyphenols from Lycopus lucidus Turcz. Food Chem. 2009, 113, 134-138. [CrossRef]

40. Kurin, E.; Mučaji, P.; Nagy, M. In Vitro Antioxidant Activities of Three Red Wine Polyphenols and Their Mixtures: An Interaction Study. Molecules 2012, 17, 14336-14348. [CrossRef]

41. Miláčková, I.; Meščanová, M.; Ševčíková, V.; Mučaji, P. Water leaves extracts of Cornus mas and Cornus kousa as aldose reductase inhibitors: The potential therapeutic agents. Chem. Pap. 2017, 71, 2335-2341. [CrossRef]

42. Bittner Fialová, S.; Kurin, E.; Trajčíková, E.; Jánošová, L.; Šušaníková, I.; Tekel’ová, D.; Nagy, M.; Mučaji, P. Mentha Rhizomes as an Alternative Source of Natural Antioxidants. Molecules 2020, 25, 200. [CrossRef] [PubMed]

43. Adomako-Bonsu, A.G.; Chan, S.L.; Pratten, M.; Fry, J.R. Antioxidant activity of rosmarinic acid and its principal metabolites in chemical and cellular systems: Importance of physico-chemical characteristics. Toxicol. in Vitro 2017, 40, 248-255. [CrossRef] [PubMed]

44. Alagawany, M.; Abd El-Hack, M.E.; Farag, M.R.; Gopi, M.; Karthik, K.; Malik, Y.S.; Dhama, K. Rosmarinic acid: Modes of action, medicinal values and health benefits. Anim. Health. Res. Rev. 2017, 18, 167-176. [CrossRef]

45. Erkan, N.; Ayranci, G.; Ayranci, E. Antioxidant activities of rosemary (Rosmarinus officinalis L.) extract, blackseed (Nigella sativa L.) essential oil, carnosic acid, rosmarinic acid and sesamol. Food Chem. 2008, 110, 76-82. [CrossRef]

46. Nadeem, M.; Imran, M.; Aslam Gondal, T.; Imran, A.; Shahbaz, M.; Muhammad Amir, R.; Wasim Sajid, M.; Batool Qaisrani, T.; Atif, M.; Hussain, G.; et al. Therapeutic Potential of Rosmarinic Acid: A Comprehensive Review. Appl. Sci. 2019, 9, 3139. [CrossRef]

47. De Martino, L.; Mencherini, T.; Mancini, E.; Aquino, R.P.; De Almeida, L.F.R.; De Feo, V. In Vitro Phytotoxicity and Antioxidant Activity of Selected Flavonoids. Int. J. Mol. Sci. 2012, 13, 5406-5419. [CrossRef] [PubMed]

48. Rice-Evans, C.A.; Miller, N.J.; Paganga, G. Structure-antioxidant activity relationships of flavonoids and phenolic acids. Free Radic. Biol. Med. 1996, 20, 933-956. [CrossRef]

49. Özgen, U.; Mavi, A.; Terzi, Z.; Kazaz, C.; Aşçı, A.; Kaya, Y.; Seçen, H. Relationship Between Chemical Structure and Antioxidant Activity of Luteolin and Its Glycosides Isolated from Thymus sipyleus subsp. sipyleus var. sipyleus. Rec. Nat. Pod. 2011, 5, 12-21. [CrossRef]

50. Cho, B.O.; Yin, H.H.; Fang, C.Z.; Ha, H.O.; Kim, S.J.; Jeong, S.I.; Jang, S.I. Synergistic Anti-inflammatory Effect of Rosmarinic Acid and Luteolin in Lipopolysaccharide-Stimulated RAW264.7 Macrophage Cells. Korean J. Food Sci. Technol. 2015, 47, 119-125. [CrossRef]

51. PhBs, I.V. Pharmacopoea Bohemoslovaca; Avicenum: Praha, Czech Republic, 1987; pp. 43-44.

52. EUCAST Documents. Available online: http://www.eucast.org/ast_of_bacteria/ (accessed on 20 April 2019).

53. Martineau, F.; Picard, F.J.; Ke, D.; Paradis, S.; Roy, P.H.; Ouellette, M.; Bergeron, M.G. Development of a PCR Assay for Identification of Staphylococci at Genus and Species Levels. J. Clin. Microbiol. 2001, 39, 2541-2547. [CrossRef]

54. DNA Sequencing of the spa Gene; Document Version 1.1, June 2004. Ridom Bioinformatics. Available online: http://www.ridom.de/doc/Ridom_spa_sequencing.pdf (accessed on 20 November 2019).

55. CLSI. Reference Method for Broth Dilution Antifungal Susceptibility Testing of Yeasts; Approved Standard-Third Edition. In CLSI Document M27-A3; Clinical and Laboratory Standards Institute: Wayne, PA, USA, 2008; Available online: https://clsi.org/media/1461/m27a3_sample.pdf (accessed on 20 November 2019).

56. Blois, M.S. Antioxidant Determinations by the Use of a Stable Free Radical. Nature 1958, 181, 1199-1200. [CrossRef]

57. Re, R.; Pellegrini, N.; Proteggente, A.; Pannala, A.; Yang, M.; Rice-Evans, C. Antioxidant activity applying an improved ABTS radical cation decolorization assay. Free Radic. Biol. Med. 1999, 26, 1231-1237. [CrossRef] 
58. Miranda-Rottmann, S.; Aspillaga, A.A.; Pérez, D.D.; Vasquez, L.; Martinez, A.L.F.; Leighton, F. Juice and Phenolic Fractions of the Berry Aristotelia chilensis Inhibit LDL Oxidation in Vitro and Protect Human Endothelial Cells against Oxidative Stress. J. Agric. Food Chem. 2002, 50, 7542-7547. [CrossRef] [PubMed]

59. Hadrich, F.; Garcia, M.; Maalej, A.; Moldes, M.; Isoda, H.; Feve, B.; Sayadi, S. Oleuropein activated AMPK and induced insulin sensitivity in C2C12 muscle cells. Life Sci. 2016, 151, 167-173. [CrossRef] [PubMed]

Sample Availability: The tested lyophilisates are available from the authors.

(C) 2020 by the authors. Licensee MDPI, Basel, Switzerland. This article is an open access article distributed under the terms and conditions of the Creative Commons Attribution (CC BY) license (http://creativecommons.org/licenses/by/4.0/). 